\title{
PENGARUH KURS RUPIAH TERHADAP INDEKS HARGA SAHAM (STUDI PADA INDEKS SAHAM SYARIAH INDONESIA PERIODE 2011-2013)
}

\author{
Imam Dwi Saputra \\ Mahasiswa Program Studi S1 Ekonomi Islam - Fakultas Ekonomi dan Bisnis, \\ Universitas Airlangga \\ Email: imamnwnc@rocketmail.com
}

Leo Herlambang

Departemen Ekonomi Syariah - Fakultas Ekonomi dan Bisnis - Universitas Airlangga Email: leo.herlambang@gmail.com

\begin{abstract}
:
Sensitivity of stock market is appeared when the domestic currency exchange rate fluctuations happened. Uncontrolled currency fluctuations will affect the performance of capital market entities which have an impact on stock price movement. This thesis is to determine the effect of exchange rate on ISSI stock price index in the 2011-2013 periods.

This thesis uses a quantitative approach to analyze secondary data which represented by exchange rate and ISSI stock price index. Those values are monthly data over the period 2011-2013. This thesis also uses a significance level of 5\%.

The regression result in this thesis indicates that the exchange rate variable has a significant effect partially on ISSI stock price index in the 2011-2013 periods.
\end{abstract}

Keywords: stock, exchange rate, Indonesia Sharia Stock Index (ISSI)

\section{PENDAHULUAN}

\section{A. Latar Belakang}

Perekonomian dunia telah memasuki era globalisasi yang memberikan pengaruh besar terhadap pergerakan modal asing yang akan masuk ke dalam pasar keuangan negaranegara berkembang. Sensitifitas pasar modal tampak ketika terjadi fenomena fluktuasi kurs mata uang domestik. Fluktuasi kurs yang tidak terkendali akan mempengaruhi kinerja badan usaha di pasar modal yang akan berdampak pada pergerakan harga saham.

Rupiah itu sendiri sering mengalami fluktuasi dari waktu ke waktu. Berdasarkan laporan akhir tahun data Bank Indonesia tentang nilai tukar rupiah terhadap dollar
Amerika per \$1 tahun 2011-2013 jumlahnya naik tajam. Berikut adalah data kurs rupiah terhadap dolar amerika:

Tabel 1.1

Kurs Rupiah terhadap US Dollar Tahun 2009-2013

\begin{tabular}{|c|c|}
\hline Tahun & USD-IDR \\
\hline 2009 & 9.447 \\
\hline 2010 & 9.036 \\
\hline 2011 & 9.113 \\
\hline 2012 & 9.718 \\
\hline 2013 & 12.250 \\
\hline
\end{tabular}

Sumber : www.bi.go.id

Saat ini banyak emiten yang dikategorikan sebagai emiten syariah. Dengan banyaknya emiten yang sahamnya dikategorikan syariah, Bursa Efek Indonesia (BEI) melalui persetujuan Dewan Syariah Nasional Majelis Ulama Indonesia (DSN-MUI) kemudian menerbitkan Indeks Saham Syariah 
Indonesia (ISSI). Fungsinya adalah untuk menampung semua saham berkategori syariah yang tercatat di BEI.

Berdasarkan data tentang fluktuatifnya kurs rupiah terhadap US dollar dan fenomena semakin berkembangnya emiten saham yang tergabung dalam Indeks Saham Syariah Indonesia maka penulis terdorong untuk melakukan penelitian dengan judul : "Pengaruh Kurs Rupiah terhadap Indeks Harga Saham (Studi pada Indeks Saham Syariah Indonesia Periode 2011-2013)".

\section{B. Rumusan Masalah}

Berdasarkan latar belakang tersebut, masalah yang akan diteliti dalam penelitian ini adalah, apakah ada pengaruh kurs rupiah terhadap indeks harga saham ISSI periode 2011-2013?

\section{Tujuan Penelitian}

Sesuai dengan rumusan masalah yang akan diteliti dalam penelitian ini, maka tujuan yang ingin dicapai adalah Mengetahui pengaruh kurs rupiah terhadap indeks harga saham ISSI periode 2011-2013.

\section{LANDASAN \\ TEORI \\ PENGEMBANGAN HIPOTESIS}

DAN

\section{A. Saham}

Kismono (2001:416) menyatakan bahwa saham merupakan sebuah piagam yang berisi aspek-aspek penting bagi perusahaan, termasuk hak dari pemilik saham dan hak khusus yang dimilikinya berkaitan dengan kepemilikan saham. Pemilik saham juga berhak mengontrol perusahaan sesuai dengan kapasitas jumlah saham yang dimilikinya melalui rapat umum pemegang saham dimana dapat menggunakan hak suara yang dimilikinya. Menurut Jogiyanto (2009:26) suatu perusahaan dapat menjual hak kepemilikannya dalam bentuk saham (stocks).

\section{B. Nilai Tukar Rupiah}

Menurut Musdholifah \& Tony (2007, dalam Triyono, 2008), nilai tukar atau kurs adalah perbandingan antara harga mata vang suatu negara dengan mata uang negara lain. Menurut Triyono (2008), kurs (exchange rate) adalah pertukaran antara dua mata uang yang berbeda yaitu merupakan perbandingan nilai atau harga antara kedua mata vang tersebut. Jadi dapat disimpulkan nilai tukar rupiah adalah suatu perbandingan antara nilai mata vang suatu negara dengan negara lain.

Heru (2008, dalam Triyono, 2008) menyatakan bahwa nilai tukar mencerminkan keseimbangan permintaan dan penawaran terhadap mata vang dalam negeri maupun mata vang asing. Semakin menguat kurs rupiah sampai batas tertentu berarti menggambarkan kinerja di pasar vang semakin menunjukkan perbaikan. Sebagai dampak meningkatnya laju inflasi maka nilai tukar domestik semakin melemah terhadap mata vang asing. Hal ini mengakibatkan menurunnya kinerja suatu perusahaan dan investasi di pasar modal menjadi berkurang. 


\section{Indeks Harga Saham Syariah}

Jogiyanto (2009:100) menyatakan bahwa suatu indeks diperlukan sebagai sebuah indikator untuk mengamati pergerakan harga dari sekuritas-sekuritas. Jogiyanto menyebutkan beberapa indeks yang dimiliki BEl sampai sekarang yaitu Indeks Harga Saham Gabungan (IHSG), Liquid Index 45 (LQ-45), Jakarta Islamic Index (JII), Indeks Saham Syariah Indonesia (ISSI), Indeks Papan Utama dan Indeks Papan Pengembangan, serta Indeks Kompas 100.

Indeks Saham Syariah Indonesia (ISSI) telah diluncurkan oleh PT Bursa Efek Indonesia (BEI) bekerja sama dengan PT Kliring Penjamin Efek Indonesia (KPEI) dan PT Kustodian Sentral Efek Indonesia pada tanggal 12 Mei 2011 di Jakarta.

\section{Hipotesis}

Berdasarkan rumusan masalah dan tujuan penelitian ini, hipotesis yang digunakan dalam penelitian ini adalah:

$H_{1}$ : Kurs rupiah berpengaruh signifikan terhadap indeks harga saham (Studi pada Indeks Saham Syariah Indonesia periode 2011-2013).

\section{E. Model Analisis}

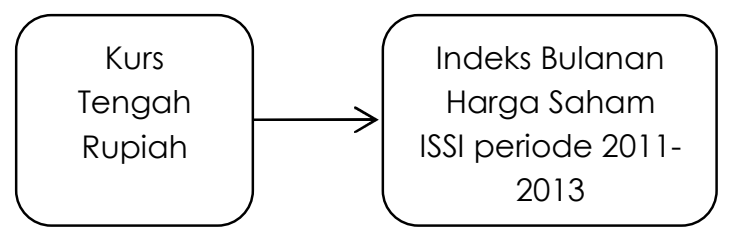

Gambar 2.1

Model Analisis

Sumber: Diolah penulis

\section{F. Kerangka Berfikir}

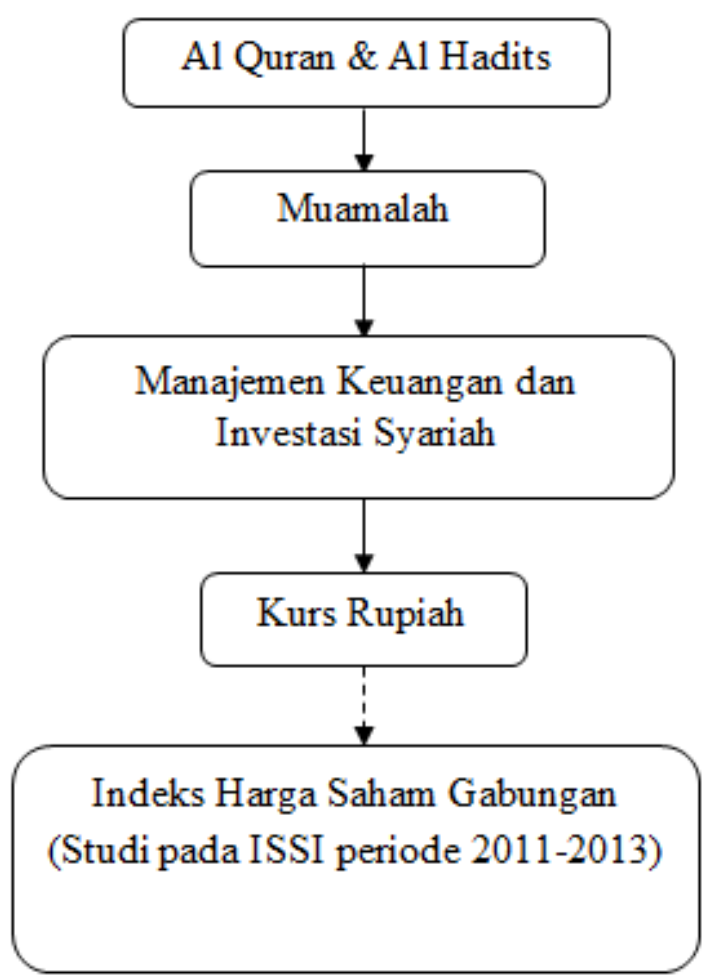

\section{Gambar 2.2}

Kerangka Berfikir

Sumber: Diolah penulis

\section{METODE PENELITIAN}

Penelitian ini menggunakan pendekatan kuantitatif dengan menggunakan data sekunder yang meliputi dua variabel yang akan diteliti dalam penelitian ini. Kedua variabel tersebut adalah variabel dependen yang diwakili oleh indeks harga saham ISSI serta variabel independen yang diwakili oleh kurs rupiah terhadap dolar amerika.

Pengujian hipotesis pada penelitian ini dilakukan dengan uji † untuk menguji apakan variabel independen yang digunakan dalam penelitian ini berpengaruh signifikan secara parsial terhadap indeks harga saham ISSI. 
Penelitian ini menggunakan tingkat signifikansi sebesar $5 \%$.

Penelitian ini menggunakan teknik analisis regresi linear sederhana dengan memanfaatkan data Kedua data tersebut merupakan data bulanan selama periode 2011-2013. Data yang diperlukan dalam penelitian ini didapatkan melalui www.idx.co.id dan www.bi.go.id. Berikut adalah model regresi penelitian yang digunakan :

$$
Y=a+\beta X+e
$$

Dimana :

$$
\begin{array}{ll}
Y & =\text { Kurs rupiah terhadap USD } \\
X & =\text { Indeks harga saham ISSI } \\
a & =\text { Konstanta } \\
\beta & =\text { Koefisien regresi } \\
\mathrm{e} & =\text { Variabel error }
\end{array}
$$

Dari model analisa regresi linear yang digunakan, terdapat beberapa asumsi klasik yang dapat digunakan untuk mengestimasi hasil agar tidak ada penyimpangan sehingga dapat memberikan informasi yang sesuai dengan data yang tersedia. Asumsi klasik tersebut adalah uji heteroskedastisitas, uji autokorelasi, dan uji normalitas.

\section{A. Populasi}

Menurut Sugiyono (2011: 80) populasi adalah wilayah generalisasi yang terdiri atas obyek/ subyek yang mempunyai kualitas dan karakteristik tertentu yang ditetapkan oleh peneliti untuk dipelajari dan kemudian ditarik kesimpulannya. Populasi dalam penelitian ini menggunakan kriteria populasi sebagai berikut:
Tabel 3.1

Kriteria Populasi

\begin{tabular}{|c|l|}
\multicolumn{2}{c}{ Kriteria Populasi } \\
\hline Variabel & \multicolumn{1}{c|}{ Keterangan } \\
\hline Kurs Rupiah & $\begin{array}{l}\text { Data yang digunakan dalam penelitian ini adalah nilai } \\
\text { kurs tengah rupiah terhadap US dollar yang dibatasi } \\
\text { pada nilai penutupan akhir bulan selama periode } \\
\text { 2011-2013 }\end{array}$ \\
\hline Indeks Harga Saham & $\begin{array}{l}\text { Indeks harga saham ISSI yang digunakan dalam } \\
\text { penelitian ini adalah harga penutupan pada akhir bulan } \\
\text { selama periode 2011-2013 }\end{array}$ \\
\hline ISSI & \\
\hline Sumber - Diolah Penulis
\end{tabular}

Pemilihan data bulanan adalah untuk menghindarkan bias yang terjadi akibat kepanikan pasar dalam mereaksi suatu informasi sehingga dengan penggunaan data bulanan diharapkan dapat memperoleh hasil yang lebih akurat. Dengan demikian diperoleh 36 data hasil dari 12 data bulanan selama 3 periode yang mana jumlah tersebut sudah memenuhi syarat lebih besar atau sama dengan 30.

\section{B. Definisi Operasional}

a. Kurs

Kurs atau nilai tukar adalah harga mata vang suatu negara terhadap mata uang negara lain. Nilai tukar yang digunakan adalah kurs rupiah terhadap US dollar, berdasarkan kurs tengah yang dihitung dari kurs jual dan kurs beli sebagaimana diatur oleh Bank Indonesia.

Kurs tengah $=\frac{\text { Kurs Jual }+ \text { Kurs Beli }}{2}$

Persamaan 3.1

Kurs atau Nilai Tukar

\section{b. Indeks Saham Syariah Indonesia}

Indeks Saham Syariah Indonesia (ISSI) adalah indeks harga yang merupakan gabungan saham syariah yang tercatat di Bursa Efek Indonesia (BEI) dan disetujui oleh DSN-MUI. Data yang digunakan adalah harga penutupan tiap akhir bulan selama periode 2011-2013 dan 
diperoleh dari kantor IDX Surabaya yang beralamat di Jl Basuki Rachmat 46.

IV. HASIL DAN PEMBAHASAN

A. Analisis Regresi Linear Sederhana

Tabel 4.1

Hasil Analisis Regresi Linear Sederhana

\begin{tabular}{|ll|l|l|l|l|l|}
\hline \multirow{2}{*}{ Model } & \multicolumn{2}{|l|}{ Unstandardized } & Standardized & & \\
\cline { 3 - 5 } & & B & Std. Error & Beta & & \multirow{2}{*}{ Sig. } \\
\hline 1 & (Constant) & 53.710 & 22.915 & & 2.344 & .025 \\
& kurs & .009 & .002 & .534 & 3.682 & .001 \\
\hline
\end{tabular}

Sumber : Hasil olah data

Berdasarkan hasil pengujian analisis regresi linear sederhana pada tabel 4.3 diatas, maka didapatkan kesimpulan sebagai berikut:

$$
Y=53.710+0.009 X
$$

Dimana variabel dependen adalah indeks harga saham (Y) sedangkan variabel independennya adalah kurs rupiah terhadap dolar amerika (X).

\section{B. Uji Heteroskedastisitas}

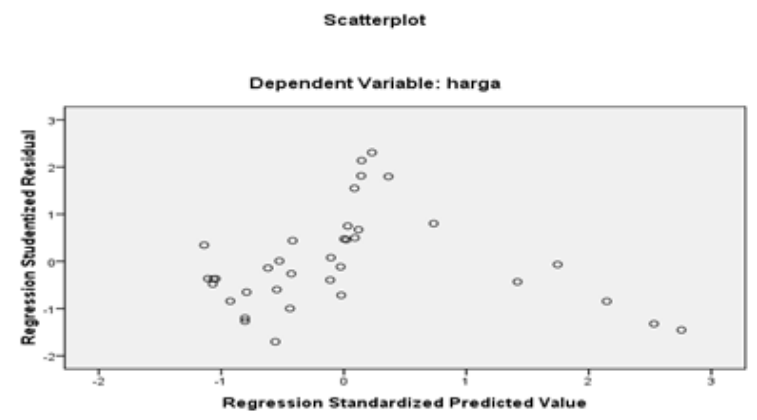

Gambar 4.1

Hasil Uji Heteroskedastisitas berdasarkan Hasil Scatterplot

Sumber : Hasil olah data

Berdasarkan gambar diatas dapat dikatakan bahwa titik-titik menyebar secara acak dan tidak membentuk suatu pola tertentu. Titik-titik data tersebut menyebar diatas dan dibawah atau sekitar angka 0 sehingga dapat disimpulkan bahwa dalam data tersebut tidak terjadi heteroskedastisitas.

\section{Uji Autokorelasi}

Dari hasil pengujian yang dilakukan dengan data-data yang telah ditentukan, diketahui bahwa nilai DW sebesar 0.327 dengan $k$ sebanyak 1 (jumlah variabel independen) dan $\mathrm{n}$ sebanyak 36 (jumlah data) maka nilai dU dan dL adalah 1.52 dan 1.41. Maka nilai autokorelasi diantara $-2<0.327<2$ jadi dapat disimpulkan bahwa tidak terjadi autokorelasi.

\section{Uji Normalitas}

\section{Normal P.P Plot of Regression Standardized Residual}

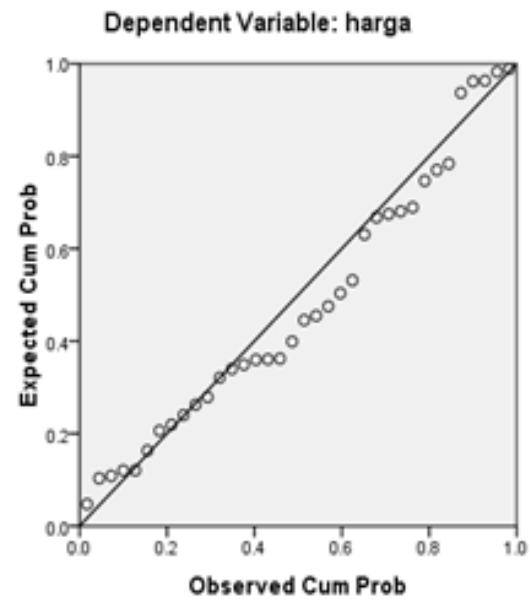

Gambar 4.2

\section{Hasil Uji Normalitas berdasarkan Hasil} Probability Plot

Sumber : Hasil olah data

Hasil output SPSS 16.0 diatas menunjukkan bahwa data menyebar disekitar garis diagonal dan mengikuti arah garis diagonal. Kesimpulan dari hasil Normal Probability Plot diatas adalah 
model regresi memenuhi asumsi normalitas.

\section{F. Uji †}

Tabel 4.3

\section{Hasil Uji $\uparrow$}

\begin{tabular}{|c|c|c|c|c|c|}
\hline \multirow[b]{2}{*}{ Model } & \multicolumn{2}{|c|}{$\begin{array}{l}\text { Unstandardized } \\
\text { Coefficients }\end{array}$} & \multirow{2}{*}{\begin{tabular}{|l} 
Standardized \\
Coefficients \\
Beta
\end{tabular}} & \multirow[b]{2}{*}{$\mathrm{t}$} & \multirow[b]{2}{*}{ Sig. } \\
\hline & B & Std. Error & & & \\
\hline (Constant) & 53.710 & 22.915 & & 2.344 & .025 \\
\hline kurs & .009 & .002 & .534 & 3.682 & .001 \\
\hline
\end{tabular}

Sumber : Hasil olah data

Variabel kurs rupiah memiliki † hitung sebesar 3.682 dengan signifikan sebesar 0.001 . Sedangkan t tabel dengan nilai signifikansi sebesar 0,05 adalah 1.978, maka t hitung $>$ t tabel $(3.682>1.978)$ dan nilai signifikan lebih kecil daripada 0,05. Dapat disimpulkan bahwa kurs rupiah berpengaruh signifikan secara parsial terhadap harga saham.

\section{G. Pembahasan}

Berdasarkan hasil pengujian secara parsial (uji †), kurs rupiah mempengaruhi indeks harga saham secara signifikan. Variabel kurs rupiah memiliki nilai $\dagger$ hitung sebesar 3.682 dengan nilai signifikansi sebesar 0.001 maka dari hasil tersebut dapat disimpulkan bahwa nilai signifikansi lebih kecil dari a 0,05. Sedangkan t tabel menunjukkan angka 1.978 maka † hitung > † tabel (3.587 > 1.978). Hasil tersebut menunjukkan bahwa kurs rupiah berpengaruh signifikan terhadap indeks harga saham ISSI. Hasil penelitian ini menyebutkan bahwa perubahan nilai yang terjadi pada kurs rupiah maka akan mempengaruhi pula perubahan nilai indeks harga saham ISSI. Kurs rupiah memiliki pengaruh positif terhadap indeks harga saham ISSI, dimana ketika kurs rupiah naik maka akan mempengaruhi kenaikan indeks harga saham ISSI sebesar 0.009. Begitu pula sebaliknya ketika kurs rupiah turun maka indeks harga saham ISSI juga akan mengalami penurunan sebesar 0.009 .

Kurs merupakan salah satu alat pengukur yang digunakan untuk menilai keteguhan suatu ekonomi. Kurs valuta asing menunjukkan harga atau nilai mata vang suatu negara dinyatakan dalam nilai mata vang negara lain. Dengan kata lain kurs adalah banyaknya uang domestik yang diperlukan untuk membeli atau memperoleh satu unit valuta asing tertentu. (Sukirno, 2004:397)

Realitanya topik keuangan internasional selalu melibatkan kurs. Kurs terjadi karena adanya perbedaan alat transaksi (mata vang) antar negara. Suatu negara yang menganut sistem perekonomian terbuka, seperti halnya Indonesia, yang melibatkan berbagai transaksi internasional, tidak dapat terpisahkan dari suatu fenomena kurs dan akibat yang ditimbulkannya. Gejolak kurs atau nilai tukar mata uang yang terjadi pada suatu negara, terutama pada suatu negara dimana dasar penukarannya seluruhnya ditentukan oleh gejolak pasar dunia, akan direspon sebagai suatu risiko yang harus diperhatikan oleh para investor, perusahaan, dan pelaku pasar 
internasional. Gejolak yang terjadi akan berdampak kepada pasar-pasar komoditi dan pasar-pasar finansial, baik dalam jangka pendek maupun jangka panjang. Sebagai gambaran, pada saat pemerintah melakukan devaluasi atau penurunan nilai mata uang terhadap mata vang asing (nilai kurs dollar terhadap rupiah naik) akan timbul kelesuan usaha, keluhan kekurangan likuiditas pada perusahaan-perusahaan, dan sebagainya.

Hubungan antara nilai tukar mata vang asing dengan harga saham diantaranya dapat dilihat melalui pendekatan pasar barang lgood market approach), dimana perubahan pada kurs akan mempengaruhi pendapatan perusahaan atau struktur cost of boundnya. Hal tersebut akan berpengaruh pada harga saham suatu perusahaan. Pada saat kurs rupiah terdepresiasi, maka biaya bahan baku impor atau produk yang memiliki kaitan dengan produk impor akan mengalami kenaikan. (Boediono, 2005:130)

Kenaikan bahan baku impor menyebabkan biaya produksi meningkat dan laba perusahaan menjadi turun sehingga tingkat dividen yang dapat dibagikan dan return yang ditawarkan akan menurun pula. Penurunan return yang ditawarkan akan mengakibatkan permintaan terhadap saham tersebut berkurang sehingga harga saham tersebut turun di pasaran. Penurunan pendapatan ini akan mendorong investor untuk melepas sahamnya. Kecenderungan para investor untuk melepas sahamnya akan menyebabkan harga saham tersebut turun. Kondisi penurunan harga saham ini akan tercermin pada indeks harga saham. Penurunan harga saham, baik yang terjadi pada perusahaan secara umum atau pun pada keseluruhan perusahaan, akan menyebabkan penurunan pada Indeks Saham Syariah Indonesia. Sebaliknya apabila terjadi penguatan nilai tukar mata vang rupiah akan berpengaruh pada kenaikan pendapatan yang ditimbulkan oleh meningkatnya volume penjualan. Peningkatan yang terjadi akan menaikkan kinerja perusahaan yang akan memunculkan optimisme investor akan kemampuan menghasilkan laba di waktu sekarang dan masa depan dari modal, sehingga akan mendorong keinginan investor untuk untuk berinvestasi pada pasar modal yang menyebabkan naiknya harga saham perusahaan. Kenaikan harga saham yang terjadi pada perusahaan secara umum atau pun keseluruhan perusahaan, akan menyebabkan peningkatan pada Indeks Saham Syariah Indonesia. Dengan demikian kurs rupiah terhadap dollar akan berpengaruh positif terhadap Indeks Saham Syariah Indonesia. Seperti yang telah dijelaskan dalam Alqur'an surat An Najm 39:

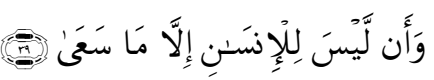

Wa'an laisa lil'insāni illā mā sa'ā.

"Dan bahwasanya seorang manusia tiada memperoleh selain apa yang telah 
diusahakannya" (Departemen Agama Rl, 2013: 874).

Bahwasanya usaha manusia yang baik atau yang buruk tidak akan dilenyapkan Allah, tetapi kelak akan diperlihatkan kepadanya sehingga ia akan berbangga dengan amal baiknya dan ingin menjauh dari amal buruknya (Shihab, 2009:204). Ayat di atas menjelaskan bahwa manusia harus berusaha dalam memperoleh apa yang diinginkannya. Setelah mengetahui bahwa kurs berpengaruh signifikan positif terhadap indeks harga saham yang tergabung dalam ISSI, hendaknya menggunakan ilmu itu sebagai referensi untuk menganalisis harga saham tersebut. Apabila investor menggunakan ilmu-ilmu yang berkaitan dengan bagaimana menganalisis harga saham, salah satunya adalah pengaruh kurs, tentu investor memiliki peluang lebih besar untuk menganalisis harga saham secara lebih akurat. Karena pada akhirnya, tujuan utama investor adalah mendapatkan keuntungan dari selisih harga saham dengan menggunakan alat-alat analisis yang dipunyai.

Hasil penelitian ini sesuai dengan hasil penelitian yang dilakukan oleh Nugraha (2013) yang menyimpulkan bahwa kurs rupiah berpengaruh signifikan terhadap indeks harga saham.

\section{SIMPULAN}

Berdasarkan hasil penelitian dan pembahasan yang telah dilakukan mengenai pengaruh kurs rupiah terhadap indeks harga saham ISSI maka simpulan yang dapat diambil adalah:

Variabel kurs rupiah berpengaruh signifikan secara parsial terhadap indeks harga saham Indeks Saham Syariah Indonesia (ISSI) periode 2011-2013. Pengaruh signifikan kurs rupiah terhadap indeks harga saham ISSI adalah positif. Dengan demikian kenaikan tingkat kurs rupiah akan menyebabkan kenaikan juga pada tingkat indeks harga saham ISSI. Sebaliknya penurunan kurs rupiah juga akan menyebabkan turunnya indeks harga saham ISSI.

\section{DAFTAR PUSTAKA}

Boediono. 2005. Seri Sinopsis Pengantar IImu Ekonomi No 3 : Ekonomi Internasional. Edisi Pertama. Yogyakarta: PT BPFE

Jogiyanto, HM. 2009. Teori Portofolio dan Analisis Investasi. Edisi Keenam. Yogyakarta: PT BPFE

Kismono, Gugup. 2001. Pengantar Bisnis. Edisi Pertama. Yogyakarta: PT BPFE Nugraha, Adit Tia. 2013. Analisis Pengaruh SBI, Kurs Rupiah, Harga Emas Dunia, Indeks Hang Seng, dan Indeks Nikkei 225 terhadap IHSG (Studi Kasus Bursa Efek Indonesia Periode 2008-2011). Skripsi tidak diterbitkan. Jakarta Fakultas Ekonomi UIN Syarif Hidayatullah

Shihab, Quraish. 2009. Tafsir Al Mishbah Volume 6. Jakarta: Lentera Hati

Sugiyono. 2011. Statistika untuk Penelitian. Bandung: Alfabeta 
JESTT Vol. 1 No. 12 Desember 2014

Sukirno, Sadono. 2004. Makroekonomi Teori

Pengantar. Edisi Ketiga. Jakarta: Rajawali Pers

Triyono. 2008. Analisis Perubahan Kurs Rupiah Terhadap Dollar Amerika. Jurnal Ekonomi Pembangunan. Vol
9 No 2. Desember 2008: 156-167.

Universitas Muhammadiyah

Surakarta

www.bi.go.id

www.idx.co.id 